\title{
MAQASHID AL-SYARI'AH DALAM KAJIAN TEORITIK DAN PRAKTEK
}

\author{
Siti $\operatorname{Sarah}^{*(a, 1)}$ dan Nur Isyanto*(b,2) \\ Sekolah Pascasarjana UIN Syarif Hidayatullah \\ Sekolah Tinggi Agama Islam Nurul Iman \\ 1 sitisarah_21@mhsuinjkt.ac.id*; 2 nurisyanto@stai-nuruliman.ac.id*
}

\begin{abstract}
Abstact
Maqashid al-Shari'ah is an alternative in an effort to solve socio-religious problems in the current era. This is because it is

Received:

03-12-2021

Revised:

09-12-2021

Published:

28-12-2021 realized that the texts, both the Qur'an and Hadith as the main sources of Islamic law, are very limited in number while social problems continue to emerge one after another. The purpose of this paper is to describe the concept of maqashid alsyari'ah both at the theoretical level and in its application. This study is included in the category of library research by utilizing data or information from ushul figh books as a primary source, then assisted by some information obtained from journals, other relevant books as secondary sources. The data obtained were described and then analyzed. This paper finds that: 1) maqashid al-syar'iah is part of qa'idah ushuliyyah and also approaches in understanding the texts of the Qur'an and the Prophet's Hadith. 2) Mujtahids must understand maqashid al-syariah in an effort to capture and interpret the divine verses hidden behind their textual folds. 3) Maqashid al-Sharia as an approach, needs to be refreshed and rearranged according to the current context.
\end{abstract}

Keywords: Approach, Maqashid al-Shari'ah, Qa'idah Ushuliyyah

Abstrak Maqashid al-Syari'ah menjadi alternatif dalam dalam upaya memecahkan problemantika sosial keagamaan di

Diterima:

03-12-2021

Direvisi:

09-12-2021

Dipublikasi: era saat ini. Demikian ini karena disadari bahwa nash

28-12-2021 baik al-Qur'an maupun Hadits sebagai sumber utama hukum Islam,jumlahnya sangat terbatas sedangkan problem sosial terus bermunculan silih berganti. Tujuan tulisan ini adalah untuk mendeskripsikan konsep maqashid al-syari'ah baik dalam tataran teori maupun aplikasinya. Kajian ini masuk dalam kategori kajian kepustakaan (library research) dengan memanfaatkan data atau informasi dari buku ushul fikih sebagai sumber primer, kemudian dibantu dengan beberapa informasi yang didapatkan dari jurnal, buku lain yang relevan 
sebagai sumber sekunder. Data yang didapatkan dideskripsikan kemudian dianalisis. Tulisan ini menemukan bahwa: 1) maqashid al-syar'iah merupakan bagian dari qa'idah ushuliyyah dan juga pendekatan dalam memahami nash al-Qur'an maupun Hadits Nabi. 2) Mujtahid harus memahami maqashid al-syariah dalam upaya menangkap dan menafsirkan ayat-ayat Illahiyah yang tersembunyi di balik lipatan-lipatan tekstualnya. 3) Maqashid al-syariah sebagai pendekatan, perlu direfresh dan ditata ulang sesuai dengan konteks kekinian.

Katakunci : Pendekatan, Maqashid al-Syari'ah, Qa'idah Ushuliyyah

\section{PENDAHULUAN}

Maqashid al-Syari'ah dalam kajian Ushul Fiqih menempati posisi penting, karena mengkaji tentang tujuan penetapan hukum dalam Agama Islam. ${ }^{1}$ Sebagian ulama menempatkannya dalam bahasan Ushul Fiqih, dan ulama lain membahasnya sabagai bahasan tersendiri serta diperluas dalam "Filsafat Hukum Islam" dengan tidak mengurangi kedudukannya sabagai bahasan dalam Filsafat Hukum Islam, namun tetap menjadikannya sebagai bagian dari bahasan Ushul Fiqh. ${ }^{2}$

Maqashid al-Syari'ah telah menjadi kajian para ilmuwan islam dalam hal kedudukannya sebagai sandaran hukum islam. Sebagian ilmuwan Islam menyatakan bahwa Maqashid al-Syari'ah boleh menjadi sandaran hukum islam karena itu merupakan hasil dari pada rumusan yang menyeluruh dan mendalam terhadap nash-nash wahyu. sebahagian yang lain menyatakan Maqashid al-Syari'ah tidak boleh menjadi sandaran hukum syara' tetapi ia hanya menjadi panduan saja dalam menentukan hukum syara' karena telah

1 Taha Jabir al-Alwani, Metodologi Hukum Islam Kontemporer, terj. Yusdani (Yogyakarta, UII Press: 2001), hal. 15-38.

2 Amir Syarifuddin, Ushul Fiqh, jilid. 2, Jakarta: Logos Wacana Ilmu, 2001), hal. 205. 
terdapat dalil- dalil yang telah disepakati oleh ilmuwan Islam sejak zaman silam yang boleh menjadi sandaran hukum. ${ }^{3}$

Makalah ini membahas tentang Maqashid alSyari'ah yang merupakan bagian dari kaidah ushuliyah yang ditemukan di banyak kitab ushul fiqh. Kaidah Ushuliyah adalah hukum kulli yang dapat dijadikan patokan hukum bagi juz'i yang diambil dari landasan kulli yaitu al-Qur'an dan as- Sunnah. Oleh karena itu aturan Ushuliyyah bisa dikatakan istinbathiyah atau aturan lughawiyah. ${ }^{4}$

Abdul Wahab Khalaf membagi kaidah ushuliyah dalam dua bagian, yaitu al-qawấ'id al-ushôliyyah allughawiyyah dan al-qawấ'id al-ushûliyyah al-tasyri'iyyah. Pembagian pertama melihat sumber ajaran Islam dari aspek- aspek kebahasaan seperti, Thariq dalalah, mafhum mukhalafah, wadhih wa ghairu wadhih, musytarik, 'am wa khas. Sedangkan yang kedua melihat pada tujuan umum pembentukan hukum islam (Maqashid al-Syari'ah), hak Allah dan hak mukallaf, pada masalah apa saja yang boleh di-ijtihadi, tentang naskh hukum dan pada taa'rrud dan tarjih. ${ }^{5}$

\section{METODE}

Penelitian ini merupakan jenis penelitian library research (kepustakaan) dan menggunakan pendekatan kualitatif. Sumber data primer diperoleh dari buku-buku dan kitab ushul fikih, sedangkan sumber data sekunder

3 Muhammad Nazir Alias dkk., "Maqasid Syariah Sebagai Sandaran Hukum Menurut Mąhab Syafie" 2 (2018): hal. 49-50.

4 Alfian Qodri Azizi, "Penggunaan Metode Kaidah Ushuliyah Dalam Memahami Nash Secara Tekstualis Dan Kontekstual," Journal of Islamic Studies and Humanities 5, no. 1 (2020): hal. 17.

${ }^{5}$ Abdul Wahab Khalaf, Ilmu Ushul Fiqh (Kairo: al-Haramain, 2004), hal. 223- 224.

Tasyri': Journal of Islamic Law, 
berupa buku, artikel jurnal yang berkaitan dengan tema pembahasan. Data yang diperoleh dianalisis dengan menggunakan teknik deskripstif analisis, dimana data-data tersebut didiskripsikan kemudian dianalisis dengan menggunakan teori Miles and Hubermen, yaitu reduksi data, penyajian data dan penarikan kesimpulan.

\section{PEMBAHASAN}

\section{A. Definisi Maqashid al-Syari'ah}

Secara bahasa, Maqasid merupakan bentuk jama dari mufrad maqshud yang berasal dari lafad qashada yang berarti tujuan. ${ }^{6}$ Audah menambahkan, maqashid berarti tujuan, sarana, hal yang diminati, atau tujuan akhir. ${ }^{7}$ Istilah ini dapat disamakan dengan istilah "ends" dalam bahasa Inggris, "telos "dalam bahasa Yunani, "finalite "dalam Bahasa Perancis, atau "zweck"dalam bahasa Jerman. Adapun dalam ilmu syari'at, al-maqâshid dapat menunjukkan beberapa makna seperti al-hadaf (tujuan), al-garad (sasaran), al-mathlub (hal yang diminati), ataupun al-gayah (tujuan akhir) dari hukum Islami. Di sisi lain, sebagian ulama Muslim menganggap maqâshid sama dengan al-Mashâlih (maslahatmaslahat) seperti Abdul Malik al-Juwainy (w: 478 H / 1185 M). Al-Juwainy termasuk ulama pertama yang memulai mengembangkan teori al-Maqshid. Al-Juwainy menggunakan istilah maqasid dan al-Mashâlih al-'Ammah (maslahah- maslahah publik) sebagai sinonim. ${ }^{8}$

Sedangkan secara istilah, Maqashid al-Syari'ah ialah tujuan akhir beserta rahasia- rahasia yang telah ditetapkan Allah SWT di dalam segala aspek hukum-

${ }^{6}$ Umar ibn Shaleh ibn Umar, Maqâshid al-Syari" ah Inda Izzuddin ibn Abd al-Salam, (Daar AnNafais, 2003), hal. 83.

7 Jasser Audah, Maqâshid al-Syariah Falsafah li al-Tasyri' al-Islami, (London: al-Ma'had al 'Alami li al-Fikr al-Islami, 2007), hal. 15. hal. 3 .

${ }^{8}$ Jasser Audah, Maqâshid al-Syariah Falsafah li al-Tasyri' al-Islami,..., 
hukumnya. ${ }^{9}$ Ibn'Asyur menyatakan bahwa Maqashid alSyari'ah adalah makna- makna dan hikmah- hikmah yang diperlihatkan oleh Allah SWT dalam semua atau sebagian besar syariat-Nya, juga termasuk dalam wilayah ini sifat- sifat syariat atau tujuan umumnya. ${ }^{10}$ Satria Effendi menyebutkan bahwa Maqashid al-Syari'ah berarti tujuan Allah SWT dan Rasul-Nya dalam merumuskan hukum- hukum Islam. Tujuan itu dapat ditelusuri dalam ayat- ayat al-Qur an dan Sunnah Rasulullah sebagai alasan logis bagi rumusan suatu hukum yang berorientasi kepada kemaslahatan manusia. ${ }^{11}$ Dalam pengertian yang lain, Maqashid alSyari'ah adalah suatu permulaan yang memuat jawaban dari suatu pertanyaan berikut dengan contohnya dengan memuat apa yang dimaksudkan oleh syariat Islam. Seperti, hikmah di balik kewajiban mengeluarkan zakat adalah untuk kemaslahatan bersama. ${ }^{12}$

Maqasid juga dapat dianggap sebagai sejumlah tujuan (yang dianggap) Ilahi dan konsep akhlak yang melandasi proses al-tasyri' al-islam (penyusunan hukum berdasarkan Syari'at Islam, seperti prinsip keadilan, kehormatan manusia, kebebasan kehendak, kesucian, kemudahan, kesetiakawanan, dan sebagainya. ${ }^{13}$

${ }^{9}$ Umar ibn Shaleh ibn Umar, Maqâshid al-Syari" ah Inda Izzuddin ibn Abd al-Salam,.., hal. 88 .

${ }^{10}$ Ghilman Nursidin, Konstruksi Pemikiran Maqâshid Syariah Imam alHaramain al-juwaini (Kajian Sosio-Histois), thesis, (Semarang: IAIN Walisongo, 2012), hal.8

11 Satria Efendi, M. Zein., Ushul Fiqh, jilid 1 (Jakarta:Prenada Media,2005), hal. 233 hal. 14.

12 Jasser Audah, Maqâshid al-Syariah Falsafah li al-Tasyri' al-Islami,..., hal. 5 .

${ }^{13}$ Jasser Audah, Maqâshid al-Syariah Falsafah li al-Tasyri' al-Islami,..., 
Dari beberapa pengertian tesebut dapat disimpulkan bahwa maqasid adalah puncak dari tujuan yang dirumuskan oleh Allah SWT dalam segala aspek hukumnya untuk kemaslahatan manusia.

\section{B. Sejarah Maqashid al-Syari'ah}

Sejarah yang melatarbelakangi sebuah teks alQur'an atau instruksi Nabi Muhammad SAW, dapat dikembalikan ke zaman sahabat Nabi, sebagaimana telah diriwayatkan tentang sejumlah kejadian pada zaman itu. Salah satu contoh yang cukup terkenal yakni yang telah diriwayatkan melalui banyak silsilah perawi adalah kejadian shalat Ashar di Bani Quraidhah ${ }^{14}$

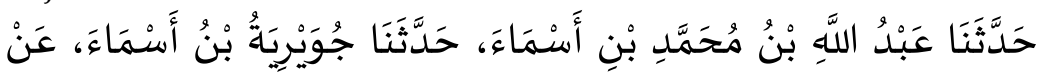

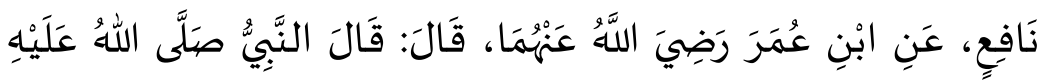

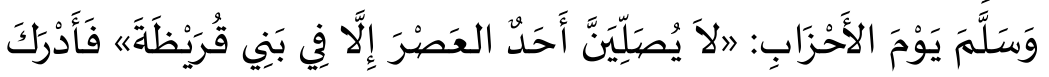

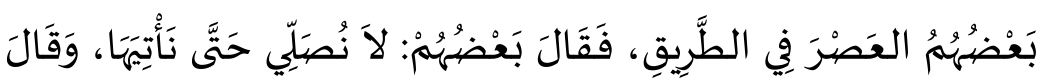

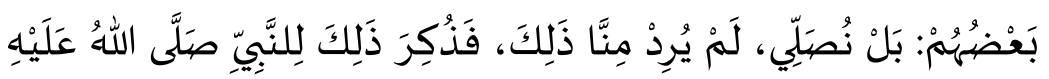

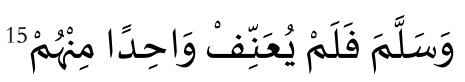

Telah menceritakan kepada kami 'Abdullah bin Muhammad bin Asma' berkata, telah menceritakan kepada kami Juwairiyah dari Nafi' dari Ibnu 'Umar berkata, "Nabi shallallahu 'alaihi wasallam bersabda kepada kami ketika beliau kembali dari perang Ahzab: "Jangan sekali-kali salah seorang dari kalian shalat 'Ashar keculi di perkampungan

${ }^{14}$ Jasser Audah, Fiqh al-Maqâshid: Inathah al-Abkam al-Syar'iyyah bi Maqâshidiha (Herndon, USA: al-Ma"had al-Fikr al-Islami, 2006), hal.15.

15 Muhammad bin Ismail Abu Abdillah al-Bukhari, Shahih Bukhari, Hadits no. 4119, Kitab al-Magazi, Bab Marjiu nabi min ahzab marjiuhu ila bani quraidhah, Juz 5 (Mesir: Dar at-Tauqi an- Najah, 1422 h), hal. 112. 
Bani Quraizhah." Lalu tibalah waktu shalat ketika mereka masih di jalan, sebagian dari mereka berkata, 'Kami tidak akan shalat kecuali telah sampai tujuan', dan sebagian lain berkata, 'Bahkan kami akan melaksanakan shalat, sebab beliau tidaklah bermaksud demikian'. Maka kejadian tersebut diceritakan kepada Nabi shallallahu 'alaihi wasallam, dan beliau tidak mencela seorang pun dari mereka.

Al-Suhaily dan yang lainnya berkata hadits ini merupakan bagian dari fiqh, tidak mengapa bagi orang yang mengambil (hukum) dari dhahirnya hadits atau ayat. Dan juga tidak mengapa bagi yang mengistimbat dari nash dengan makna khusus (bathinnya). Karena mereka berselisih tentang furu' dan bagi yang berijtihad dapat ganjaran. ${ }^{16}$

Berdasarkan hadits tersebut di atas bahwa Nabi SAW membenarkan juga sahabat yang memaknai perkataan Nabi 'agar cepat- cepat sampai' sehingga shalat terlebih dahulu. Ini dilakukan semata- mata menghindari 'tarku shalah' yang merupakan larangan keras demi maslahah. Jadi mempertimbangkan demi maslahah dibolehkan dan sudah ada sejak zaman Nabi SAW.

Al-Raysuni menyimpulkan bahwa sepanjang perkembangan usul fiqih, Maqashid al-Syari'ah mengalami perkembangan besar melalui tiga tokoh sentral, yaitu Imam al-Haramain Abu al-Ma'alî Abdullâh al-Juwainy (w. $478 \mathrm{H}$ ), Abu Ishaq al-Shathiby (w. $799 \mathrm{H}$ ), dan Muhammad al-THahir Ibn 'Asyur (w. 1379 H/ 1973 M). ${ }^{17}$ Melalui ketiga tokoh inilah tonggak dan era penting

16 al-Hafidz Ahmad bin 'Ali bin Hajar al-'Asqalani, Fathul Bari, Juz 7 (Mesir: Maktabah Taufiqiyyah, 2008) h. 518.

17 Ahmad Imam Mawardi, Fiqih Minoritas, Fiqh Al-Aqalliyyat dan Evolusi Maqashid al-Shariah dari Konsep ke Pendekatan, (Yogyakarta: LKiS, 2010), ha1. 80-184.

Tasyri': Journal of Islamic Law, 
di mana Maqashid al-Syari'ah betul- betul tampak mengalami pergeseran makna. Ulama maqasidiyyun sepakat bahwa nilai-nilai maqashid ini dasar utamanya adalah al Qur'an dan al-Hadits, yang nashh-nya senantiasa menegaskan nilai- nilai, tujuan, 'illat, dan hikmah yang terkandung di dalamnya. Tapi, pengungkapan nilai- nilai, hikmah, 'illat, dan tujuan syariat ke dalam suatu tema besar bernama maqashid belum ditemukan pada masa- masa awal perkembangan hukum Islam. ${ }^{18}$

Sementara itu dari perspektif pencetus awal disiplin keilmuan maqashid, Jasser Auda mencatatkan beberapa ulama. Pertama, al-Tirmizi al-Hakim (w. 296 H/908 M) mendedikasikan karya terkenal pertama bagi topik maqashid pada bukunya yang berjudul al-SHalah wa Maqashiduha (Shalat dan Maqasidnya). Buku ini berisi sekumpulan hikmah dan "rahasia" spiritual di balik setiap gerakan salat, dengan kecenderungan sufi. Contohnya adalah "menegaskan ketundukan" sebagai maqashid di balik pengagungan kepada Allah SWT. melalui setiap gerakan dalam shalat; 'mencapai kesadaran' sebagai maqâshid di balik memuji kepada Allah SWT; 'memfokuskan shalat seseorang' sebagai maqashid di balik menghadap Ka'bah; kedua, Abu Zaid al-Balkhi (w. 322 H/933 M) dalam karya terkenal pertama tentang maqashid muamalah, al-Ibânah 'an 'ilal alDiyânah (Penjelasan Tujuan- tujuan di balik Praktikpraktik Ibadah), di mana dia menelaah maqasid di balik hukum- hukum yuridis Islam; ketiga, al-Qaffal al-Kabîr (w. $365 \mathrm{H} / 975 \mathrm{M}$ ) menulis manuskrip terkuno terkait topik 'maqashid Mahâsin al-Shara'i' (Keindahankeindahan Hukum Syariat); keempat, Ibn Babawih al-

18 M Nur Fauzi, "Menimbang Urgensitas Maqasid Al-Shariah Dan Aplikasinya Di Era Kontemporer,” 2020., hal. 158.

Tasyri': Journal of Islamic Law, 
Qummî (w. 381 H/991 M). Bukunya tentang maqâshid berjudul 'Ilal al-Shara' $i$ ' (Alasan- alasan di balik Hukum syariat), 'merasionalisasikan' keimanan kepada Allah, kenabian, surga dan rukun iman lainnya. Buku ini juga memberikan rasionalisasi moral terhadap shalat, puasa, haji, zakat, berbakti kepada orang tua, dan kewajiban lain; kelima, al-'Amirî al-Failasuf (w. 381 H/991 M) mengajukan klasifikasi teoretik pertama terhadap maqâshid dalam karyanya 'al-I'lam bi Manaqib al-Islâm' (Pemberitahuan tentang Kebaikan-kebaikan Islam). Klasifikasi ini semata- mata berdasarkan 'hukum pidana' (hudûd) dalam hukum Islam. ${ }^{19}$

al-'Amirî al-Failasuf adalah seorang filsuf dan ahli kalam, yang berbeda dengan pengkaji Maqashid al-Syari'ah sebelumnya yang rata- rata hanya memiliki expertise (keahlian) dalam bidang fiqih. Dengan pendekatan filosofisnya, ia menyatakan dalam kitab perbandingan agamanya yang monumental al-I'lam bi al-Manaqib al-Islam, bahwa dalam rangka membangun kehidupan individu dan sosial yang baik dipastikan adanya lima pilar yang harus ditegakkan, yang tanpanya kemaslahatan tidak akan pernah terealisasi. Lima hal itu adalah: mazjarah qatl al-nafs (sanksi hukum untuk pembunuhan jiwa), mazjarah akhdh al-mal (sanksi hukum untuk pencurian harta), mazjarah fath al-satr (sanksi hukum untuk membuka 'aib), mazjarah thalbal-'irdh (sanksi hukum untuk perusakan atau pencelaan kehormatan), dan mazjarah khal' al-baydhah (sanksi hukum untuk pelepasan kehormatan dan ketulusan). Lima poin inilah yang kemudian menjadi cikal- bakal al-dlarûriyyat alkhamsah yang menjadi sentral points kajian Maqashid al-

${ }^{19}$ Fauzi, hal. 59.

Tasyri': Journal of Islamic Law, 
Syari'ah setelahnya, seperti al- Juwaynî, al- Ghazali, dan sebagainya. ${ }^{20}$

Pasca para pencetus awal teori maqashid di atas, konsep ini terus mengalami evolusi yang signifikan. Para ulama maqashidiyyun di era ini di antaranya adalah, pertama, Abu al-Ma'ali al-Juwainy (w. 478 H/1085 M). Karya al-Juwainy yang berkaitan dengan maqashid terdapat dalam dua karyanya, yakni al-Burhan fi Ushul alFigh (Dalil- dalil Nyata dalam Usul fiqh) dan Ghiyas alUmam (Penyelamat Umat-umat). Dalam al-Burhan, alJuwainy memperkenalkan teori tingkatan dharuriyyah, dengan cara yang mirip dengan teori tingkatan keniscayaan yang familier saat ini. Dia menyarankan lima tingkatan maqashid, yaitu keniscayaan (dharuriyyah), kebutuhan public (al-hajah al-'âmmah), perilaku moral (al-makrumat) anjuran- anjuran (almandubat) dan 'apa yang tidak dapat dicantumkan pada alasan khusus'. Dia mengemukakan bahwa maqashid hukum Islam adalah kemaksuman (al-'ishmah) atau penjagaan keimanan, jiwa, akal, keluarga, dan harta. Sementara itu dalam al-Burhan, al-Juwainy memberi kontribusi penting terhadap teori maqashid yang tujuan utamanya terkait dengan isu politik. ${ }^{21}$

Menurut al-Juwainy seperti dikutip oleh Mohammad Hashim Kamali bahwa pentingnya pengetahuan mengenai Maqashid al-Syari'ah ini didasarkan pada bahwa para sahabat Nabi menunjukkan kesadaran tingkat tinggi akan tujuan syariat, dan menambahkan bahwa "seseorang yang tidak bercermin

20 Ahmad Imam Mawardi, Fiqih Minoritas, Fiqh Al-Aqalliyyat dan Evolusi Maqashid al-Shariah dari Konsep ke Pendekatan, (Yogyakarta: LKiS, 2010), hal. 191.

21 Fauzi, "Menimbang Urgensitas Maqasid Al-Shariah Dan Aplikasinya Di Era Kontemporer,” Hal. 160. 
pada maqashid sesungguhnya melakukan sesuatu yang membahayakan dirinya dan kemungkinan tidak memiliki pemahaman yang dalam tentang syariat". ${ }^{22}$

Kedua, Abu Hamid al- Ghazali (w. 505 H/ 1111 M). al- Ghazali mengembangkan teori gurunya dalam kitabnya al-Mustasfa (Sumber yang Dijernihkan). alGhazâlî mengurutkan 'kebutuhan' yang disarankan alJuwainy dengan keimanan, jiwa, akal, keturunan, dan harta. Al-Ghazali juga mencetuskan istilah 'perlindungan (al-hifz) terhadap kebutuhan-kebutuhan ini. ${ }^{23}$

Al-Ghazali menjadi istimewa dalam kajian Maqashid al-Syari'ah karena keberhasilannya menjabarkan aspek al-dharuriyyat al-khamsah, yang tanpanya maslahah dinyatakan tidak ada. Dialah orang pertama yang memberikan nama al-dharuriyyat al-khamsah, menjelaskan secara memadai dan menyusunnya dengan urutan agama, jiwa, akal, keturunan, dan harta sebagai hal- hal yang dilindungi oleh Islam. Kitabnya yang berjudul alMustashfa fi 'Ilm al-Ushul menjelaskan tentang hal ini. Dengan penjelasannya yang lengkap mengenai konsepsi maslahah dan prinsip- prinsip teoretis hukum Islam, alGhazâlî dikukuhkan dalam sejarah usul fiqih sebagai peletak dasar ilmu usul fiqih. Menurut al-Ghazâlî, al-usûl al-khamsah merupakan ajaran yang tidak saja diajarkan oleh Islam, tetapi juga diajarkan dan menjadi prinsip seluruh agama (milal) yang menghendaki terciptanya kemaslahatan bagi manusia di muka bumi ini. Oleh karenanya, lanjut al -Ghazâlî, tidak ada satu agama pun yang tidak melarang kufur, pembunuhan, zina,

22 Mohammad Hashim Kamali, Membumikan Syariah Pergulatan Mengaktualkan Islam (Bandung: Mizan, 2013), 166.

23 Fauzi, "Menimbang Urgensitas Maqasid Al-Shariah Dan Aplikasinya Di Era Kontemporer,” hal. 160. 
pencurian, dan mengkonsumsi sesuatu yang dapat merusak atau mengganggu fungsi akal. ${ }^{24}$

Ketiga, al- Izz al-Din Ibn Abd as- Salam (w. 660 H/1209 M). al- Izz menulis dua buku tentang maqashid dalam nuansa hikmah di balik hukum Islam, yaitu Maqâshid al-SHhalah (Maqashid shalat) dan Maqashid ashSHhaum (Maqasid Puasa). Tetapi kontribusi signifikannya terhadap perkembangan teori maqashid adalah bukunya tentang kemaslahatan yang berjudul Qawa'id al-Ahkam fi Masalih al-Anam (Kaidah-kaidah hukum bagi Kemaslahatan Umat manusia); Keempat, Syihab al-Din al-Qarafî (w. 684 H/1285 M) kontribusi al- Qarafi terhadap teori maqashid adalah diferensiasi antara jenisjenis perbuatan Nabi berdasarkan 'maksud/ niat 'beliau; kelima, Syams ad-Din Ibn al-Qayyim (w. 748 H/1347 M). Kontribusi Ibn Qayyim terhadap teori maqashid adalah melalui kritiknya yang sangat mendetail terhadap triktrik fikih (al-hiyal al-fiqhiyyah), berdasarkan fakta bahwa hal tersebut bertentangan dengan maqashid Ibn Qayyim; Keenam, al-Imam Abu Ishaq Ibrahim Ibn Musa Ibn Muhammad al-Lakhmi al-Syathiby al-Gharnathy (w. 790 H/ $1388 \mathrm{M}$ ). Dua kitabnya yang fenomenal adalah alI'tishham dan al-Muwafaqat fi Ushul asy-Syariah. alMuwafaqat adalah kitab yang membahas secara luas tentang Maqashid al-Syari'ah, tidak hanya menjabarkan definisi dan konsep nilai yang dibawanya, tetapi sampai pada kaidah- kaidah dasar yang harus dilalui dalam berpikir dengan dasar konsiderasi Maqashid al-Syari'ah . Al-Syathiby berhasil menampilkan wajah baru Maqashid al-Syari'ah yang lebih dinamis dan aplikatif. ${ }^{25}$

${ }^{24}$ Halil Thahir, Ijtihad Maqasidi Rekonstruksi Hukum Islam Berbasis Interkoneksitas Maslahah, (Yogyakarta: LKiS, 20), 38

25 Fauzi, "Menimbang Urgensitas Maqasid Al-Shariah Dan Aplikasinya Di Era Kontemporer," hal.61. 
Dalam perkembangannya, muncul pilar ketiga dengan hadirnya seorang sarjana bernama Muhammad al-THhahir Ibn 'Asyur (w. 1379 H/ 1973 M). Karyanya yang terkenal adalah Maqashid al-Syariah al-Islamiyyah. ${ }^{26}$ Dalam waktu yang hampir bersamaan juga hadir tokoh lain, yakni 'Alal al-Fasyi (w. $1394 \mathrm{H}$ ) dengan kitabnya yang bernama Maqashid al-Syariah wa Makarimuha. Banyak kesamaan ide dan pemikiran dari dua tokoh asal Maghrib ini, salah satu contohnya adalah: pandangan yang menyatakan bahwa maqashid syar'iyyah berdiri di atas fitrah manusia. Berangkat dari firman Allah SWT dalam surat al- Rum ayat 30 dan surat al-A'râf ayat 119, THhahir Ibn 'Âshyur dan 'Alal al-Fasyi sepakat bahwa menjaga fitrah manusia adalah termasuk dalam Maqashid al-Syari'ah, untuk itu, syariat Islam tidak akan pernah bertentangan dengan akal manusia selama ia dalam kondisi normal. Kemudian muncullah para pengkaji maslahah seperti Muhammad Sa'id Ramadhhan al-Buthi, dengan kitabnya, Dawâbit al-Mashlahah fi al-Syarîah alIslâmiyyah. Mustafa Zaid, ia menulis buku tentang maslahah, berjudul al-Mashlahah fi al-Tashrî'i al-Islâmi. Musthafa Syalabi, dengan kitabnya, Ta'lîl al-Ahkam, Husain Hamid Hasan, dengan kitabnya, Nadhâriyyat alMashlahah fi al-Figh al-Islâmî. ${ }^{27}$

Hal baru lainnya yang dilakukan oleh Ibn 'Âsyur adalah keberaniannya meletakkan hurriyyah (kebebasan/ freedom yang berbasiskan al-musâwah atau egalitarianisme), fitrah (kesucian), samahah (toleransi), alhaq (kebenaran dan keadilan) sebagai bagian dari aplikasi Maqashid al-Syari'ah. Kebebasan berbicara, berpendapat, beragaman dan bertindak nerupakan hak asasi manusia yang dilindungi. Pernyataan seperti ini tentu merupakan

${ }^{26}$ Mawardi, Fiqib Minoritas,..., hal. 195-196

${ }^{27}$ Halil Thahir, Ijtihad Maqasidi Rekonstruksi,..., hal. 34-35 
pengembangan dari al-dharuriyyat al-khams yang digagas oleh ulama sebelumnya. Pengembangan ini bukan hanya dari sisi tambahan kuantitas unsur maqâshid, melainkan juga dari sisi kualitas efek penetapan unsur- unsur maqashid syar'iyyah itu sendiri. Pembagian maqashid syar'iyyah menjadi al-dharuriyyat al-khams hanya berfungsi lebih sebagai proteksi terhadap diri, sementara unsur kebebasan, keadilan, kesucian, dan egalitarianisme menekankan fungsi progresif Islam yang lebih umum. ${ }^{28}$

Pasca Ibn 'Âsyûr hingga saat ini, Maqashid alSyari'ah menapaki jalan menuju puncak kejayaan, dengan indikator utama dijadikannya Maqashid al-Syari'ah sebagai rujukan dan dalil pokok dalam menjawab sebagian besar persoalan kontemporer, Terakhir yaitu Jaser Auda dengan bukunya yang berjudul Maqâshid alSyariah Falsafah li al-Tasyri' al-Islami atau yang berbahasa inggris Maqâshid al-Syariah as Philosophy of Islamic Law. ${ }^{29}$

\section{Konsep Maqashid al-Syari'ah}

Maqashid al-Syari'ah adalah konsep untuk mengetahui nilai- nilai dan sasaran yang mengandung syara' yang tersurat dan tersirat dalam al-Qur'an dan Hadits. Ditetapkan Allah SWT terhadap manusia dan tujuan akhir hukum tersebut adalah satu, yaitu mashlahah atau kebaikan dan kesejahteraan umat manusia baik di dunia maupun di akhirat. Dan untuk mencapai kemaslahatan tersebut manusia harus memenuhi

28 Fauzi, "Menimbang Urgensitas Maqasid Al-Shariah Dan Aplikasinya Di Era Kontemporer,” hal. 165.

29 ML Hakim, "Pergeseran Paradigma Maqasid Al-Syari'ah: Dari Klasik Sampai Kontemporer," Al-Manahij: Jurnal Kajian Hukum Islam, no. 25 cites: https://scholar.google.com/scholar?cites=14873666119875712508 \& as_sdt $=2005 \quad \& \quad$ sciodt $=2007 \quad \& \quad \mathrm{hl}=\mathrm{en} \quad(2016)$ : hal. 11., http://ejournal.iainpurwokerto.ac.id/index.php/almanahij/article/view/913 
kebutuhan dharurriyat (Primer), dan Menyempurnakan kebutuhan hajiyat (sekunder) dan tahsinat atau kamaliat (tersier) $)^{30}$

Berbicara mengenai ruang lingkup Maqashid alSyari'ah, sudah banyak tulisan yang berusaha membahasnya, sehingga terdapat banyak pendapat ulama, bergantung dimensi yang dipandang oleh fiqih atau ulamanya. Jasser Audah memberikan kesimpulan bahwa klasifikasi klasik Maqashid al-Syari'ah meliputi 3 (tiga) jenjang keniscayaan: al-Dharuriyyat, al-Hajiyyah, dan al-Tahsiniyyat. ${ }^{31}$ Sedangkan Izzuddin ibn Abd alSalam menyebutkan dengan tiga skala prioritas yaitu aldharuriyyat, al-hajiyyat dan al-takmilat atau al-tatimmat. ${ }^{32}$ Kemudian para ulama membagi daruriyyat menjadi 5 (lima): hifdz al-Dîn (perlindungan agama), hifdz al-Nafs (perlindungan jiwa), hifdz al-Mâl (perlindungan harta), hifdz al-Aql (perlindungan akal), dan hifdz al-Nasl (perlindungan keturunan). Sebagian ulama menambahkan hifdz al-'Ird (perlindungan kehormatan) untuk menggenapkan kelima maqasid itu menjadi enam tujuan pokok/ primer atau al-daruriyyat.

Penetapan dalam untuk menentukan dasar hukum maqashid syar'iyyah bisa dinyatakan secara spesifik sebagai tujuan dari syariat melalui tiga cara penetapan, menurut Asy-Syatiby, ada tiga cara penetapan, yaitu: 1) cukup mengetahui dalil perintah atau larangan yang secara jelas, bahwa tujuan yang dikehendaki adalah kepatuhan dengan menjalankan perintah dan meninggalkan larangan, 2) dengan

30 Abdurrahman Misno B.P, Maqashid Al-Syariah, bttp:/ / majelispenulis.blogspot.in/2013/09/Maqashid-al-syariab-tujuan-bukum-Islam hal. 15.

${ }^{31}$ Jasser Audah, Maqâshid al-Syariah Falsafah li al-Tasyri' al-Islami,...,

32 Amir Muallim dan Yusdani, Konfigurasi Pemikiran Hukum Islam, ed.1, cet.1, (Yogyakarta: UII Press, 1999), hal. 53 
memandang 'illat- 'illat dari perintah atau larangan, seperti pensyariatan nikah yang bertujuan untuk memelihara keturunan, 3) bahwa dalam penerapan hukum syari'at, syar'i memiliki tujuan pokok (Maqashid Ashliyyah) dan tujuan pelengkap (Maqashid tabi'ah). Adakalanya tertera secara eksplisit, tersirat secara implisit, ataupun didapatkan dari hasil penulusuran (istigra') terhadap nash. Sehingga dapat disimpulkan bahwa setiap maqashid yang tidak tertera dalam nash namun tidak bertentangan dengan ketentuan diatas, termasuk juga dalam Maqashid al-Syari'ah ${ }^{33}$

Subtansi teori Maqashid al-Syari'ah adalah mewujudkan kemaslahatan hamba dengan cara mendatangkan manfaat bagi mereka dan menolak kemudharatan dari mereka. Dalam hal ini, menurut alSyâthiby, al-maqashid al-syar'iyyah sebagai pembuat hukum dan maqâshid al-mukallaf, tujuan mukallaf sebagai pelaksana hukum.

Dalam pembahasan maqashid syar'iyyah, alSyâthiby membagi kategori ini ke dalam empat aspek yang terdiri dari:

1. Tujuan awal Syari'at, yakni kemaslahatan manusia di dunia dan akhirat. Aspek ini berkaitan dengan hakikat Maqashid al-Syari'ah .

2. Syariat sebagai sesuatu yang harus difahami. Aspek ini berkaitan dengan urgensi bahasa agar syariat dapat difahami dan mashlahah dapat dicapai.

3. Syariat sebagai hukum taklif yang harus dilaksanakan. Aspek ini berkaitan dengan pelaksanaan ketentuan syari'at dalam rangka merealisasikan mashlahah. Selain itu juga berkaitan

33 Abu Ishaq Ibrahim bin Musa bin Muhammad Allakhmy As Syatiby, Kitab Al Muwafaqoot (Penerbit Dar Ibn Qayyim; 2003), h. 78. 
dengan kemampuan manusia dalam melaksanakan syari'at.

4. Tujuan syariat dalam membawa manusia ke bawah naungan hukum. Aspek ini berkaitan dengan kepatuhan manusia sebagai mukallaf terhadap syariat, di mana ia bertujuan untuk membebaskan manusia dari kekangan hawa nafsu. ${ }^{34}$

al-Syâthiby mengeksplorasi bahwa mashlahah ini dapat diwujudkan bila lima unsur pokok dalam syari'ah dapat direalisasikan, yakni: Pertama, Pemeliharaan atas agama (hifzh al-din). Kedua, Pemeliharaan atas jiwa (hifzh al-nafs). Ketiga, Pemeliharaan atas akal (hifzh al-'aql). Keempat, Pemeliharaan atas keturunan (hifzh al-nasl). Kelima, Pemeliharaan atas harta (hifzh al-mâl). ${ }^{35}$

Lima unsur pokok di dalam syariah ini dalam istilah jurisprudensi Islam disebut dengan al-mabadi' alkhamsah atau al-ushul al-khamsah yang berarti lima unsur pokok. Sebelum al-Syâthiby, teori ini sudah pernah diformulasikan dan dipublikasikan oleh para ulama pendahulu al-Syâthiby, seperti al- Ghâzali dalam kitabnya, al-Mustashfâ min 'Ilm al-Ushûl. ${ }^{36}$ Namun konsep ini kemudian dikembangkan secara sistematis oleh alSyâthiby, sehingga al-Syâthiby dalam hal ini dinobatkan sebagai pencetus teori Maqashid al-Syari'ah .

Sebagaimana telah disinggung sebelumnya bahwa subtansi maqashid syar'iyyah adalah mashlahah. suatu hal baru dianggap sebagai mashlahah bila mendatangkan manfaat dan menolak kemudharatan. Menurut

${ }^{34}$ Al-Syâtțibî, al-Muwâafaqat fi Ushûl al-Ahkeâm, Jld II, IV, (Beirut: Dar al-Fikr, tt), hal. 62-63

35 Al-Syâtịibi, al-Muwâfaqat fi Ushûl..., hlm. 64

36 Al-Ghazali, al-Mustashfâ min 'Im al-Ushûl, Jld I, (Beirut: Dar Ihya' al-turats al-'Arabi, nd), hal. 287

Tasyri': Journal of Islamic Law, 
Muhammad Thahir ibn 'Asyûr, Mashlahah itu dapat dilihat dari tiga sudut pandang, yaitu:

1. Dari sisi kekuatan dan pengaruhnya untuk kesejahteraan umat. Pada aspek ini, mashlahah terbagi tiga macam, yaitu:

a. Dharuriyat

Secara bahasa dharûriyat berarti kebutuhan yang mendesak. Dharûriyat ini dikatakan mendesak karena merupakan sendi dari eksistensi kehidupan manusia yang harus ada. Mashlahah dharûriyat adalah sesuatu yang mesti ada bagi manusia demi tegaknya kemaslahatan agama dan dunia. Apabila hal ini tidak ada, maka akan menimbulkan kerusakan, dan terancamnya kehidupan dunia dan kehidupan akhirat. Mashlahah ini disebut sebagai mashlahah primer. Yang termasuk ke dalam mashlahah dharûriyat adalah: Pertama. Pemeliharaan atas agama (hifzh al-dîn). Kedua. Pemeliharaan atas jiwa (hifzh alnafs). Ketiga. Pemeliharaan atas akal (hifzh al- 'aql). Keempat. Pemeliharaan atas keturunan (hifzh alnasl), dan kelima pemeliharaan atas harta (hifzh almâl).

b. Hâjiyat

Mashlahah hâjiyat adalah sesuatu yang sebaiknya ada bagi keteraturan hidup manusia, agar mereka terhindar dari kesulitan. Kalau sesuatu ini tidak ada, maka ia tidak akan menimbulkan kerusakan atau kematian, hanya saja akan mengakibatkan masyaqqah dan kesulitan. Mashlahah seperti ini disebut mashlahah sekunder. Hukum- hukum yang lahir berdasarkan pertimbangan mashlahah hâjiyat terdapat dalam semua bab- bab fiqh. Dalam masalah ibadat seperti rukhsah melakukan jama' dan qashar shalat bagi orang musafir. Dalam fiqh 
yang berdimensi adat seperti dibolehkan memakan binatang buruan. Dalam figh muamalat seperti dibolehkan akad al-qiradh, al-salam, dan lain-lain. sedangkan dalam figh jinayat seperti menetapkan terhadap keluarga si pembunuh. ${ }^{37}$

c. Tahsiniyat

Mashlahah Tahsinat adalah sesuatu yang sebaiknya ada demi sesuainya dengan keharusan akhlak yang baik atau dengan adat. Kalau sesuatu ini tidak ada, maka tidak akan menimbulkan kerusakan atau hilangnya sesuatu, juga tidak akan menimbulkan masyaqqah dalam melaksanakannya, hanya saja dinilai tidak pantas dan tidak layak menurut ukuran tatakrama dan kesopanan. mashlahah seperti ini disebut mashlahah tersier. Di antara contohnya dalam fiqh ibadat adalah thaharah, menutup aurat, dan menghilangkan najis. Dalam fiqh adat seperti adab makan dan minum. Dalam fiqh muamalat seperti larangan menjual benda yang najis. Sedangkan dalam figh jinayat seperti larangan membunuh wanita dan anak- anak dalam peperangan. Pembagian mashlahah pada tiga hal tersebut, sekaligus menunjukkan peringkat kepentingannya masingmasing.

2. Dari sisi keterkaitannya dengan kepentingan umum dan individu. Pada aspek ini, mashlahah terbagi dua macam, yaitu:

a. Kulliyah

Mashlahah kulliyah adalah mashlahah yang kembali kepada kepentingan umat Islam secara umum, atau kepada kelompok yang besar. Muhammad Thahir ibn 'Asyûr memberi contoh mashlahah ini

37 Al-Syâttibî, al-Muwâfaqat fi Ushâl..., hlm. 64 
seperti menjaga dua tanah haram (makkah dan Madinah) agar jangan sampai jatuh ke tangan orang-orang kafir. Demikian pula masalahmasalah lain di mana kemaslahatannya ditujukan untuk umum. Dan bila kemaslahatan ini tidak tercapai maka mafsadahnya juga kembali kepada umat secara umum.

b. Juz'iyah

Mashlahah juz'iyah adalah mashlahah yang kembali kepada individu umat atau golongan yang kecil dari mereka. Menurut Ibn 'Asyûr, contoh contoh kemaslahatan ini sudah tercover dalam semua hukum- hukum syari'at yang berhubungan dengan muamalat. 38

3. Dari sisi tingkat kebutuhan kepadanya. Pada aspek ini, mashlahah terbagi tiga, yaitu:

a. Qath'iyyah

Mashlahah qath'iyyah adalah mashlahah yang dipahami dari dalil- dalil berupa nash yang tidak mempunyai kemungkinan takwil. Selain itu, termasuk juga ke dalam mashlahah qath'iyah apa saja yang bisa dikategorikan sebagai mashlahah dharuriyat, dan hal- hal yang menurut akal terdapat kemaslahatan yang besar.

b. Zhanniyah

Mashlahah zhanniyah adalah apa saja hasil penalaran akal yang bersifat zhanniy, seperti memelihara anjing di rumah sebagai penjaga pada saat merasa terancam. Termasuk juga mashlahah zhanniyah, masalah-maslah yang bersumber kepada dalil zhanniy.

c. Wahmiyyah

38 Muhammad Thahir ibn 'Asyûr, Maqâshid al-Syâri'ah..., hal. 90. 
Mashlahah wahmiyyah adalah hal- hal yang dianggap kemaslahatan melalui khayalan semata. Ketika penalaran dilakukan secara mendalam, didapatkan bahwa sebenarnya hal- hal tersebut merupakan kemudharatan. Seperti mengkonsumsi minuman keras dan obat- obat terlarang.

\section{Maqashid al-Syari'ah dalam Kajian Teoritik dan Praktek}

Maqashid al-Syari'ah terdapat beberapa unsurunsur pokok yang menjadi tujuan pokok dalam pembahasannya yaitu:

1. Perlindungan terhadap agama (Hifzh al-Din)

Agama Islam merupakan agama yang menjaga hak dan kebebasan serta bertoleransi dengan agama lain, dan kebebasan dalam Islam yang pertama adalah kebebasan berkeyakinan dan beribadah. Setiap pemeluk agama berhak atas agamanya dan alirannya. Islam mengajarkan untuk tidak memaksa seseorang untuk masuk dalam ajaran Islam, karena setiap manusia mempunyai hak dalam menentukan keyakinannya. Dasar hak ini sesuai dengan firman Allah SWT QS. alBaqarah/ 256;

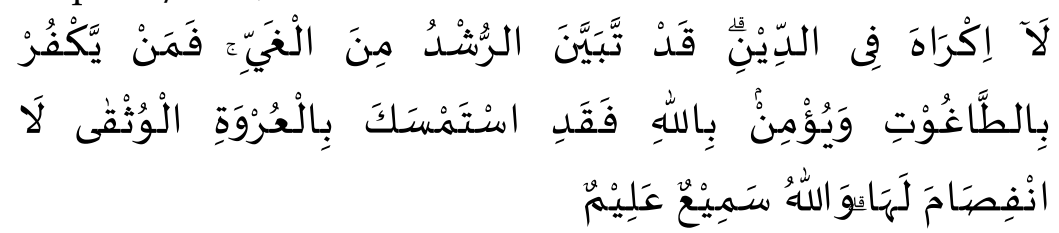

Tidak ada paksaan dalam (menganut) agama (Islam). Sungguh, telah jelas jalan yang benar dari jalan yang sesat. Siapa yang ingkar kepada taghut dan beriman kepada Allah sungguh telah berpegang teguh pada tali yang sangat kuat yang tidak akan putus. Allah Maha Mendengar lagi Maha Mengetahui. 
Dalam perlindungan agama (Hifzh al-Din) agar penerapan dalam beragama berjalan dengan aman, tentram dan sesuai syariat Islam, maka diperlukan perlindungan dan penjagaan untuk pribadi dengan mengharamkan perbuatan yang bersifat memata- matai, menganiaya dan menyakiti tanpa sebuah alasan yang masuk akal atau benar. Seperti kita ketahui juga dalam sebuah negara kita mempunyai hak- hak dalam menjalankan hidup ini, maka dari itu Islam berpegang teguh dalam hak- hak ini dan meyakinkan bahwa setiap manusia walaupun non muslim tetap menjadi manusia yang diberikan perhatian dan saling menjaga serta berakhlak mulia sesama manusia. Hal ini juga kembali di jelaskan dalam firman Allah dalam QS.An-Nahl / 90:

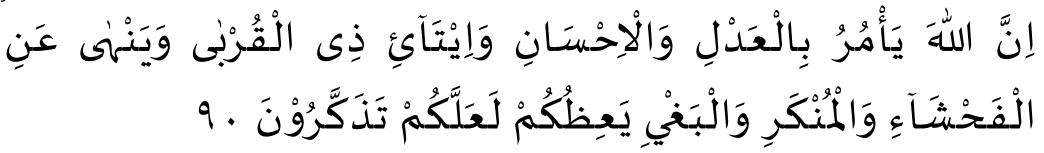

Sesungguhnya Allah menyuruh berlaku adil, berbuat kebajikan, dan memberikan bantuan kepada kerabat. Dia (juga) melarang perbuatan keji, kemungkaran, dan permusuhan. Dia memberi pelajaran kepadamu agar kamu selalu ingat.

Dari ayat tersebut, sudah secara jelas dan gamblang bahwa dalam suatu negara dengan berbagai undang- undang yang dibuat harus memperhatikan hukum secara adil dan memberikan jaminan hak kepada setiap manusia untuk segala urusan dan mencegah saling menganiaya antar sesama manusia. ${ }^{39}$ Dalam perlindungan agama (hifzh al-Din) bisa dibedakan menjadi tiga tingkatan sesuai dengan kepentingannya yakni:

Hifzh al-din dalam tingkatan Dharruriyat, yaitu memelihara dan melaksanakan kewajiban keagamaan

39 Ahmad Al-Mursi H.J, Maqashid Syariah (Cet. III; Jakarta: Amzah; 2013), h. 18 
yang termasuk tingkatan primer, seperti melaksanakan shalat lima waktu, jika kewajiban shalat ini di abaikan maka eksistensi agama akan terancam. Begitu pula pelaksanaan ibadah haji, jika tidak difasilitasi maka rukun islam yang kelima akan punah. Hifzh al-din dalam tingkatan Hajjiyat, yaitu melaksanakan ketentuan agama dengan maksud menghindarkan kesulitan seperti pensyar'iatan shalat jamak dan qasar bagi seorang yang sedang berpergian. Jika ketentuan ini tidak dilaksanakan maka tidak akan mengancam eksistensi agama, melainkan hanya akan mempersulit orang yang akan melakukannya. Hifzh al-din dalam tingkatan Tahsiniyyat, yaitu mengikuti petunjuk Agama guna menjunjung tinggi martabat manusia sekaligus menyempurnakan pelaksanaan kewajiban terhadap Tuhan. Misalnya, menutup aurat, membersihkan badan, pakaian, dan tempat tinggal. Pelaksanaan ini erat kaitannya dengan akhlak mulia. Jika tidak dilakukan, karena memungkinkan, maka tidak akan mengancam eksistensi agama dan tidak pula mempersulit orang yang melakukannya. ${ }^{40}$

Salah satu contoh kongkret dalam Hifzh al-din, Islam mewajibkan ibadah, misalnya haji. Demi kelancaran pelaksanaan tujuan primer ini dibutuhkan fasilitas haji, misalnya transportasi. Tanpa transportasi, orang masih dapat menunaikan ibadah haji tetapi akan menghadapi banyak masalah. Kalau harus berjalan dari jakarta ke Madinah dan Makkah, misalnya, maka akan memakan banyak waktu, biaya, atau tenaga. Jika berjalan kaki di padang pasir sepanjang jalan ini berakibat fatal maka transportasi di sini tidak lagi hanya dibutuhkan tetapi meningkat menjadi niscaya (dharury), karena

H.M. Hasbi Umar, Nalar Fiqh Kontemporer (Jakarta: Penerbit Persada Press; 2007), hal. 124

Tasyri': Journal of Islamic Law, 
pelaksanaan ibadah tidak boleh berarti bunuh diri. Pada tahap tersier, maka transortasi yang akan digunakan diserahkan kepada rasa estetika dan kemampuan lokal. Di sini akan terjadi variasi. Mungkin ada yang memilih jalan darat dengan naik unta, mobil, atau kereta api. Mungkin ada yang memilih jalur laut dengan naik perahu layar, kapal api atau kapal selam. Sebagian mungkin lebih suka menggunakan jalur udara dengan naik pesawat Boeing atau yang lain. Masing- masing berdasarkan pada pertimbangan estetika dan kemampuan lokal. Di sini tampak jelas bahwa pengharusan menggunakan jalur dan jenis kendaraan tertentu dapat menimbulkan mafsadat: terbunuhnya banyak spesialisasi dan lapangan kerja di bidang transportasi. ${ }^{41}$

2. Perlindungan terhadap Jiwa (Hifdz An-Nafs)

Menjaga hak hidup merupkan suatu tindakan yang terhormat dalam ajaran Islam, tetapi dalam konteks abad sekarang ini, jiwa hanya merupakan sesuatu yang tidak penting bagi umat manusia di muka bumi ini, banyak terjadi kelakuan- kelakuan yang dibuat oleh manusia yang mengorbankan nyawanya namun tidak sesuai dengan syariat Islam, seperti membunuh diri atau melakukan kesengajaan untuk menghilangkan nyawa seseorang. Hal ini merupakan hal yang dikecam oleh Allah SWT dalam firman-nya di QS. An-Nisa /29:

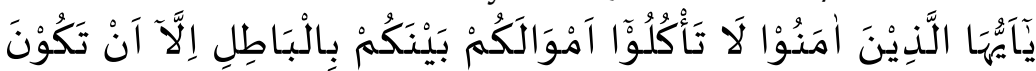

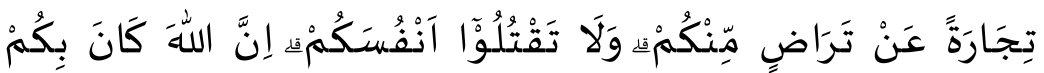

41 Fauzi, "Menimbang Urgensitas Maqasid Al-Shariah Dan Aplikasinya Di Era Kontemporer," hal. 177. 
Wahai orang-orang yang beriman, janganlah kamu memakan harta sesamamu dengan cara yang batil (tidak benar), kecuali berupa perniagaan atas dasar suka sama suka di antara kamu. Janganlah kamu membunuh dirimu. Sesungguhnya Allah adalah Maha Penyayang kepadamu.

Untuk tujuan penjelasan inti dari ayat tersebut kita bisa melihat bahwa tindakan membunuh ataupun bunuh diri berarti menghancurkan sifat (keadaan) dan mencabut ruh manusia. Padahal kita ketahui bahwa hanya Allah lah yang pantas untuk mencabut dan meniupkan ruh kepada seluruh manusia di muka bumi ini dalam konteks antara kematian dan pembunuhan mempunyai perbedaan yang mendasari kalimat keduanya. Pembunuhan tidaklah sama dengan kematian, karena pembunuhan adalah meruysak struktur tubuh yang menyebabkan keluarnya ruh yang berada pada manusia itu dalam kondisi sehat dengan spesifikasispesifikasi khusus dengan adanya unsur kesengajaan di dalamnya yang dilakukan oleh sesama manusia. Sedangkan kematian adalah keluarnya ruh dari tubuh dengan keadaan sehat dan hanya Allah SWT lah yang mematikannya. ${ }^{42}$

Termasuk dalam perlindungan jiwa dalam agama Islam atau jiwa manusia bahwa Islam memberikan hak kepada suatu jiwa yang di berikan oleh Allah SWT termasuk suatu jiwa yang masih berada dalam janin. Seperti kehidupan di zaman sekarang ini kebanyakan seorang wanita yang berzina dan menghasilkan suatu nyawa di dalam perutnya, namun tidak diinginkan maka wanita tersebut melakukan tindakan (Aborsi), padahal hal ini juga dilarang oleh ajaran Islam terkecuali apabila ada beberapa faktor yang benar- benar harus 2013), h. 27

${ }^{42}$ Ahmad Al-Mursi H.J, Maqashid Syariah (Cet. III; Jakarta: Amzah; 
menggugurkan janin tersebut ialah dikhawatirkan ibu darti janin tersebut meninggal atau sebab lain.

Berdasarkan kepentingannya memelihara jiwa ini dapat di bedakan menjadi tiga tingkatan yaitu: Memelihara jiwa dalam tingkatan dharruriyah, seperti pensyaria'tan kewajiban memenuhi kebutuhan pokok berupa makanan untuk mempertahankan hidup. Jika kebutuhan pokok itu diabaikan maka akan berakibat terancamnya eksistensi jiwa manusia. Dalam tingakatan hajjiyat yaitu seperti dibolehkannya untuk berburu dan menikmati makanan yang halal dan bergizi. Jika ketentuan ini diabaikan maka akan mengancam eksitensi manusia, melainkan hanya akan mempersulit hidupnya. Dalam tingkatan tahsiniyat yaitu seperti, disyariatkannya aturan tata cara makan dan minum. Ketentuan ini hanya akan berhubungan dengan etika atau kesopanan. Jika diabaikan maka ia tidak mencancam eksitensi manusia ataupun mempersulit kehidupan manusia.

Termasuk juga dalam Hifdz An-Nafs, syariat islam melarang bagi seorang muslim untuk membunuh atau melenyapkan nyawa, bunuh diri, berzina, aborsi (tanpa sebab), membiarkan orang kelaparan, merusak atau menjual organ- organ tubuh. Hal itu semua semata- mata untuk memelihara jiwa (Hifdz An-Nafs).

Bagaimana cara untuk memelihara jiwa? untuk menyelamatkan jiwa, Islam mengharuskan manusia menjaga kesehatan. Demi kelancaran proses perwujudan tujuan primer ini dibutuhkan berbagai sarana, misalnya olahraga. Tanpa olahraga, orang bisa saja menjaga kesehatan, misalnya dengan cara makan dan tidur yang teratur, tetapi kehadiran olah raga akan membantu menyempurnakan kedua sikap di atas. Pada tahap tersier, olah raga yang akan dipilih diserahkan kepada rasa estetika dan kemampuan lokal dengan berbagai 
variasi. Masing-masing pilihan diserahkan pada rasa estetika dan kemampuan lokal, karena pengharusan menggunakan jenis olah raga tertentu akan menimbulkan mafsadat, yaitu terbunuhnya banyak spesialisasi dan lapangan kerja di bidang olah raga. 43

3. Perlindungan terhadap akal ( $\mathrm{Hifdz}$ al-Aql)

Akal merupakan sumber hikmah yang diberikan oleh Allah SWT kepada umat manusia untuk dipergunakan sesuai dengan hakekatnya, akal ini merupakan sinar hidayah, dan pengetahuan yang diberikan kepada manusia untuk dunia dan akhirat. Dengan akal surat dari perintah Allah disampaikan, dengan akal pula manusia bisa menjadi pemimpin di muka bumi ini dan membedakan manusia dengan makhluk lainnya di muka bumi ini. Hal ini sesuai dengan firman Allah SWT dalam QS. al- Isra' / 70

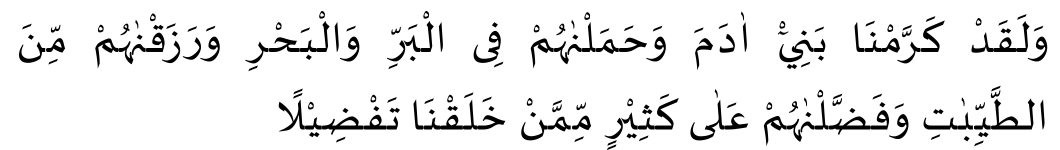

Sungguh, Kami telah memuliakan anak cucu Adam dan Kami angkut mereka di darat dan di laut. Kami anugerahkan pula kepada mereka rezeki dari yang baik-baik dan Kami lebihkan mereka di atas banyak makhluk yang Kami ciptakan dengan kelebihan yang sempurna.

Manusia yang hidup di dunia ini merupakan makhluk hidup yang paling tinggi derajatnya diantara makhluk hidup yang lainnya, seperti telah dijelaskan bahwa manusia mempunyai akal fikiran untuk melakukan sesuatu. Olehnya itu Islam mengajarkan untuk melindungi akal dari perbuatan yang tidak sejalan dengan agama Islam. Melalui akalnya manusia mendapatkan petunjuk menuju ma'rifat kepada tuhan

43 Fauzi, "Menimbang Urgensitas Maqasid Al-Shariah Dan Aplikasinya Di Era Kontemporer,” hal. 177-178. 
dan penciptanya. Tanpa akal manusia tidak berhak mendapatkan pemuliaan yang bisa mengangkatnya menuju barisan para malaikat. ${ }^{44}$

Islam memerintahkan kita menjaga akal dan mencegah bentuk kekerasan atau penganiayaan yang ditujukan untuk memperlemah akal fikiran kita untuk melakukan ajaran yang dilarang oleh Islam. Salah satu dari perbuatan yang bisa merusak akal adalah meminum minuman keras yang menyebabkan seseorang mabuk dan kehilangan sadaran serta fikiran. Seseorang akan mabuk apabila telah meminum khamr' atau minuman keras. ${ }^{45}$

Dalam tingkatannya untuk memelihara akal berdasarkan kepentingannya bisa dibagi dengan tiga tingkatan: Dalam tingkatan Dharurriyat seperti diharamkannya mengkonsumsi minuman yang memabukkan. Jika eksistensi ini tidak di lakukan maka akan mengakibatkan terancamnya gannguan akal. Dalam tingkatan hajjiyat, seperti anjuran menuntut ilmu pengetahuan. Sekiranya aktivitas ini tidak dilakukan maka tidak akan merusak akal seseorang, namun akan mempersulit diri seseorang dalam pengembangan ilmu pengetahuan. Dalam tingkatan tahsiniyat, seperti menghindarkan dari dari mengkhayal atau mendengarkan sesuatu yang tidak berguna. Hal ini berkaitan dengan etika, tidak akan mengganggu eksistensi akal secara langsung. ${ }^{46}$

Untuk menyelamatkan akal, Islam mengharuskan manusia belajar di sepanjang hayatnya. Demi kelancaran

44 Ahmad Al-Mursi H.J, Maqashid Syariah (Cet. III; Jakarta: AMZAH; 2013), hal. 92

45 Ahmad Al-Mursi H.J, Maqashid Syariah (Cet. III; Jakarta: AMZAH; 2013), hal. 106.

46 H.M. Hasbi Umar,Nalar Fiqh Kontemporer (Jakarta: Penerbit Persada Press; 2007), hal. 126

Tasyri': Journal of Islamic Law, 
proses perwujudan tujuan al-daruriyyat ini dibutuhkan lembaga pendidikan, misalnya pembidangan dari tingkat terendah hingga tingkat tertinggi. ${ }^{47}$

4. Perlindungan terhadap keturunan ( $\mathrm{Hifdz}$ an-Nasl)

Islam memberikan perhatian lebih terhadap aturan dan membersihkan keturunan dari cacat dan mengayominya dengan kebaikan atau perbaikan serta ketenangan hidup kepada keturunan tersebut. Ketika sebuah nasab merupakan pendirian yang teguh dalam kekerabatan keluarga dan penghubung antara anggota keluarga, maka Islam memberikan perhatian yang sangat besar untuk melindungi nasab dari segala sesuatu yang menyebabkan kehancuran sebuah nasab tersebut. ${ }^{48}$

Dalam penjagaan nasab atau keturunan Islam juga melarang membuat nasab keturunan dari perbuatan zina. Secara umum perbuatan zina adalah suatu perbuatan seksual yang dilakukan oleh seorang pria dan wanita tanpa adanya akad nikah atau hubungan yang mengikat secara resmi kepada dua orang tersebut, sehingga perbuatan ini diharamkan oleh agama Islam yang mana perbuatan ini mengancam eksistensi dalam kehormatan menjaga keturunan. Allah SWT telah berfirman dalam QS. An- Nur /2:

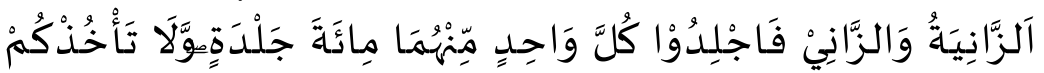

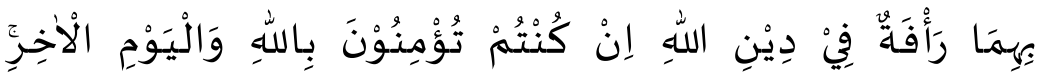

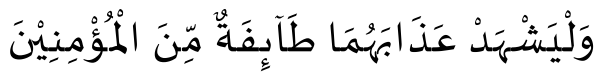

Pezina perempuan dan pezina laki-laki, deralah masingmasing dari keduanya seratus kali dan janganlah rasa belas

47 fauzi, "Menimbang Urgensitas Maqasid Al-Shariah Dan Aplikasinya Di Era Kontemporer," hal. 178.

48 Ahmad Al-Mursi H.J, Maqashid Syariah, (Cet. III; Jakarta: Amzah; 2013), hal. 143

Tasyri': Journal of Islamic Law, 
kasihan kepada keduanya mencegah kamu untuk (melaksanakan) agama (hukum) Allah jika kamu beriman kepada Allah dan hari Kemudian. Hendaklah (pelaksanaan) hukuman atas mereka disaksikan oleh sebagian orang-orang mukmin.

Dalam tingkatannya memelihara keturunan yaitu: Tingkatan dharuriyat seperti pensyari'atan hukum perkawinan dan larangan melakukan perzinahan. Apabila ketentuan ini diabaikan maka eksistensi keturunan akan terancam. Dalam tingkatan hajjiyat seperti ditetapkannya ketentuan menyebutkan mahar bagi suami pada saat akad nikah dan diberikan hak talak padanya. Jika mahar tidak disebutkan pada waktu akad, maka suami akan mengalami kesulitan karena ia di haruskan untuk membayar mahar misl. Sedangkan dalam kasus talak, suami akan mengalami kesulitan, jika ia tidak menggunakan hak talaknya, padahal situasi dan kondisinya sudah tidak harmonis lagi. Dalam tingkatan tahsiniyat seperti di syariatkan khitbah atau walimah dalam perkawinan. Hal ini dilakukan dalam rangka menyempurnakan kegiatan perkawinan. Jika ia diabaikan maka tidak akan mengancam eksistensi keturunan, dan tidak pula akan mempersulit orang yang melakukan perkawinan, ia hanya berkaitan dengan etika atau martabat seseorang. ${ }^{49}$

5. Perlindungan terhadap harta (Hifdz al-Mal)

Harta merupakan sesuatu kebutuhan inti dalam kehidupan di dunia ini, di mana manusia tidak akan pernah terlepas dari harta tersebut. Dalam kehidupan ini manusia termotivasi untuk mencari harta demi menjaga eksistensi kehidupan dan demi menambah kenikmatan materi dan religi. Namun, dalam motivasi pencarian

${ }^{49}$ Lihat, H.M. Hasbi Umar,Nalar Figh Kontemporer (Jakarta: Penerbit Persada Press; 2007), hal. 126. 
harta ini dibatasi menjadi tiga syarat yaitu, harta dikumpulkan dengan cara yang halal, dipergunakan untuk hal- hal yang halal dan dari harta ini harus dikeluarkan hak Allah dan masyarakat di tempat di mana dia hidup. ${ }^{50}$

Namun dalam penggunaan harta ini Allah SWT melarang dalam pemakaian harta yang boros yang berakibatkan sifat sombong karena harta itu sendiri. Islam juga melarang melakukan pencarian harta dengan memakan hasil riba dari orang lain, sebagaimana firman Allah SWT dalam QS. al- Baqarah /275- 276;

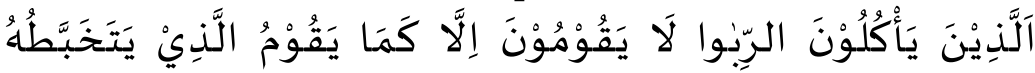

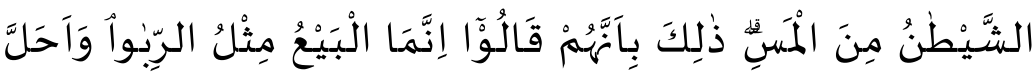

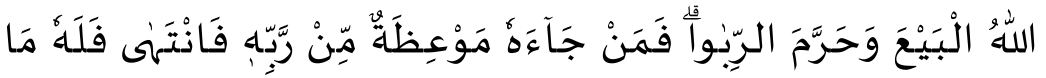

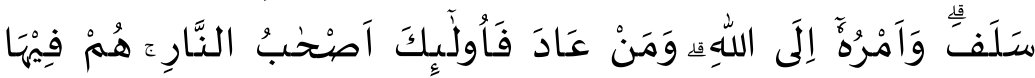
خُلِدُوْنَ كَفَّارٍ آَثِيْمِ

275.Orang-orang yang memakan (bertransaksi dengan) riba tidak dapat berdiri, kecuali seperti orang yang berdiri sempoyongan karena kesurupan setan. Demikian itu terjadi karena mereka berkata bahwa jual beli itu sama dengan riba. Padahal, Allah telah menghalalkan jual beli dan mengharamkan riba. Siapa pun yang telah sampai kepadanya peringatan dari Tuhannya (menyangkut riba), lalu dia berhenti sehingga apa yang telah diperolehnya dahulu menjadi miliknya dan urusannya (terserah) kepada Allah. Siapa yang mengulangi (transaksi riba), mereka itulah penghuni neraka. Mereka kekal di dalamnya.

50 Ahmad Al-Mursi H.J, Maqashid Syariah (Cet III; Jakarta: AMZAH; 2013), hal. 143

Tasyri': Journal of Islamic Law, 
276. Allah menghilangkan (keberkahan dari) riba dan menyuburkan sedekah. Allah tidak menyukai setiap orang yang sangat kufur lagi bergelimang dosa.

Dalam tingkatannya melindungi harta di asumsikan sebagai berikut : dalam tingkatan dharurriyat seperti pensyariatan aturan kepemilikan harta dan larangan mengambil harta orang lain dengan cara yang ilegal. Apabila aturan tersebut dilanggar maka akan mengancam eksistensi melindungi harta. Memelihara harta dalam tingkatan hajjiyat seperti disyariatkannya jual beli dengan cara salam. Apabila harta cara ini tidak dipakai maka tidak akan mengancam eksistensi harta melainkan hanya akan mempersulit seseorang yang memerlukan modal. Memelihara harta dalam tingkatan tahsiniyat seperti adanya ketentuan agar menghindarkan diri dari penipuan. Karena hal itu merupakan keterkaitan dengan moral dan etika dalam bermuamalah. Hal ini juga akan berpengaruh kepada keabsahan jual beli tersebut, sebab pada tingkatan ketiga ini merupakan syarat adanya tingkatan kedua dan pertama. ${ }^{51}$

Untuk menyelamatkan harta,

Islam

mengharuskan orang mengetahui ilmu menjaga harta. Demi kelancaran proses perwujudan tujuan dharurriyat ini dibutuhkan fasilitas menjaga harta, misalnya bank sebagai tempat penyimpanan uang. Tanpa bank, penyimpanan uang tetap bisa dilakukan misalnya di bawah tilam, di celengan, atau di kubur di suatu tempat. Namun demikian, kehadiran bank sangat membantu si pemilik dari banyak kemungkinan yang akan mengganggu, baik itu perampok, pencuri atau bahaya lain semisal kebakaran. Pada tahap tahsiniyat, pilihan

51 H.M. Hasbi Umar, Nalar Figh Kontemporer (Jakarta: Penerbit Persada Press; 2007), hal. 127.

Tasyri': Journal of Islamic Law, 
untuk menentukan bank diserahkan kepada kemantapan dan kemampuan lokal.

Adapun kajian Maqashid al-Syari'ah dalam teoritik dan praktek dapat digambarkan sebagai berikut;

\begin{tabular}{|c|c|c|c|}
\hline $\begin{array}{l}\text { Usul al- } \\
\text { Kamsah }\end{array}$ & Dalil & Aplikasi & Solusi \\
\hline $\begin{array}{l}\text { Hifzh } \\
\text { ad-Din }\end{array}$ & $\begin{array}{l}\text { QS. al- } \\
\text { Baqarah/ } \\
256, \\
\text { QS. An- } \\
\text { Nahl / } 90\end{array}$ & $\begin{array}{l}\text { - Memelihara dan } \\
\text { melaksanakan kewajiban } \\
\text { keagamaan } \\
\text { - Melaksanakan ruksoh } \\
\text { - Penyempurnaan ibadah }\end{array}$ & $\begin{array}{l}\text { Keharusan } \\
\text { beragama }\end{array}$ \\
\hline $\begin{array}{l}\text { Hifzh } \\
\text { an-Nafs }\end{array}$ & $\begin{array}{l}\text { QS. An- } \\
\text { Nisa } \\
/ 29,30\end{array}$ & $\begin{array}{l}\text { Memenuhi kebutuhan } \\
\text { pokok } \\
\text { - } \text { Dibolehkannya untuk } \\
\text { berburu dan menikmati } \\
\text { bergizi. } \\
\text { - Aturan tata cara makan } \\
\text { dan minum }\end{array}$ & $\begin{array}{l}\text { Menjaga } \\
\text { Kesehatan }\end{array}$ \\
\hline $\begin{array}{l}\text { Hifzh al- } \\
\text { Aql }\end{array}$ & $\begin{array}{l}\text { QS. al- } \\
\text { Baqarah/ } \\
173 \\
\text { QS. al- } \\
\text { Isra'/70 }\end{array}$ & $\begin{array}{l}\text { Mengkonsumsi yang } \\
\text { memabukkan } \\
\text { - Anjuran menuntut ilmu } \\
\text { pengetahuan } \\
\text { - Mengkhayal atau } \\
\text { mendengarkan sesuatu } \\
\text { yang tidak berguna. }\end{array}$ & $\begin{array}{l}\text { Belajar } \\
\text { sepanjang } \\
\text { hayatnya. }\end{array}$ \\
\hline $\begin{array}{l}\text { Hifzh } \\
\text { an-Nasl }\end{array}$ & $\begin{array}{l}\text { QS. An- } \\
\text { Nur /2 }\end{array}$ & $\begin{array}{l}\text { Hukum perkawinan dan } \\
\text { larangan melakukan } \\
\text { perzinahan } \\
\text { - Menyebutkan mahar bagi } \\
\text { suami pada saat akad } \\
\text { nikah dan -diberikan hak } \\
\text { talak padanya. } \\
\text { - Khitbah atau walimah } \\
\text { dalam perkawinan }\end{array}$ & $\begin{array}{l}\text { Melanggen } \\
\text { gkan } \\
\text { pernikahan }\end{array}$ \\
\hline
\end{tabular}




\begin{tabular}{|c|c|c|c|}
\hline $\begin{array}{l}\text { Hifzh al- } \\
\text { Mal }\end{array}$ & $\begin{array}{l}\text { QS. al- } \\
\text { Baqarah } \\
\text { /275- } 276 \\
\text { QS. al- } \\
\text { Maidah/ } \\
90\end{array}$ & $\begin{array}{l}\text { Aturan kepemilikan harta } \\
\text { dan larangan mengambil } \\
\text { harta orang lain dengan } \\
\text { cara yang illegal } \\
\text { - Jual beli dengan cara } \\
\text { salam } \\
\text { - Menghindarkan diri dari } \\
\text { penipuan }\end{array}$ & $\begin{array}{l}\text { Mengetahu } \\
\text { i ilmu } \\
\text { menjaga } \\
\text { harta }\end{array}$ \\
\hline
\end{tabular}

\section{PENUTUP}

Konsep al-maqashid al-syar'iah baik sebagai bagian dari qaidah ushuliyyah maupun pendekatan sangat relevan untuk terus dikembangkan dan dijadikan rujukan dalam menyikapi problemantika sosial keagamaan di era saat ini. Titik pointnya adalah ketika sumber- sumber hukum yang terbatas itu membeku dan terdiam dalam menyikapi realita kehidupan yang semakin berkembang sedemikian kompleksnya, maka almaqasid menjadi alternatif rujukan dalam upaya memecahkan problemantika tersebut.

Para ulama maqasidiyyun di era klasik, abad tengah hingga kontemporer menyatakan pentingnya pemahaman terhadap al-maqashid al-syariah dalam menangkap dan menafsirkan ayat- ayat Illahiyah yang tersembunyi di balik lipatan-lipatan tekstualnya. Sebagai sebuah qaidah dan pendekatan, kiranya konsep almaqashid al-syariah perlu direfresh dan ditata ulang sesuai dengan konteks kekinian. Karena gagasan atau konsep itu pun juga tidak berangkat dari ruang hampa tanpa historisitas yang mengelilinginya.

\section{DAFTAR PUSTAKA}

al- 'Asqalani, al-Hafidz Ahmad bin 'Ali bin Hajar. Fathul Bari, Juz 7. Mesir: Maktabah Taufiqiyyah, 2008. 
al- Alwani, Taha Jabir. Metodologi Hukum Islam Kontemporer, terj. Yusdani, Yogyakarta, UII Press: 2001.

al- Mursi H.J, Ahmad. Maqashid Syariah Cet. III; Jakarta: AMZAH; 2013.

Audah, Jasser. Fiqh al-maqâshid : Inathah al-Ahkam alSyar'iyyah bi Maqâshidiha, Herndon, USA: al-Ma"had al-Fikr al-Islami, 2006.

Maqâshid al-Syariah Falsafah li al-Tasyri' al-Islami, London: al-Ma' had al 'Alami li al-Fikr al-Islami, 2007.

Azizi, Alfian Qodri. "Penggunaan Metode Kaidah Ushuliyah Dalam Memahami Nash Secara Tekstualis Dan Kontekstual," Journal of Islamic Studies and Humanities 5, no. 1 (2020).

al-Bukhari, Muhammad bin Ismail Abu Abdillah. Shahih Bukhari, Hadits no. 4119, Kitab al-Magazi, Bab Marjiu nabi min ahzab marjiuhu ila bani quraidhah, Juz 5. Mesir: Dar at-Tauqi an- Najah, 1422.

Efendi, Satria, M. Zein., Ushul Figh, jilid 1, Jakarta:Prenada Media, 2005.

Fauzi, M Nur. "Menimbang Urgensitas Maqasid Al-Shariah Dan Aplikasinya Di Era Kontemporer," 2020.

al-Ghazali, al-Mustashfâ min 'Ilm al-Ushûl, Jid I, (Beirut: Dar Ihya' al-turats al-'Arabi, nd),

ibn 'Asyur, Muhammad Thahir. Maqâshid al-Syâri'ah alIslamiyah, Cet I, (Tunisia: Mathba'ah al-Faniyah, 1966. ibn Umar, Umar ibn Shaleh. Maqâshid al-Syari"ah 'Inda Izzuddin ibn Abd al-Salam, Daar AnNafais, 2003.

Kamali, Mohammad Hashim. Membumikan Syariah Pergulatan Mengaktualkan Islam, Bandung: Mizan, 2013.

Khalaf, Abdul Wahab. Ilmu Ushul Figh, Kairo: al-Haramain, 2004.

Mawardi, Ahmad Imam. Fiqih Minoritas, Figh Al-Aqalliyyat dan Evolusi Maqashid al-Shari'ah dari Konsep ke Pendekatan, Yogyakarta: LKiS, 2010. 
Misno B.P, Abdurrahman. Maqashid Al-Syariah, http://majelispenulis.blogspot.in/2013/09/Maqashi d-al-syariah-tujuan-hukum-Islam

ML Hakim, "Pergeseran Paradigma Maqasid Al-Syari'ah: Dari Klasik Sampai Kontemporer," Al-Manahij: Jurnal Kajian Hukum Islam, no. 25 cites: https:/ / scholar.google.com/ scholar?cites $=148736661$ $19875712508 \&$ as_sdt $=2005 \&$ sciodt $=2007 \& \mathrm{hl}=\mathrm{en}$ (2016)

http:/ / ejournal.iainpurwokerto.ac.id/index.php/al manahij/article/view/913.

Muallim, Amir dan Yusdani, Konfigurasi Pemikiran Hukum Islam, ed.1, cet.1, Yogyakarta:UII Press, 1999.

Nazir, Muhammad Alias dkk., "Maqasid Syariah Sebagai Sandaran Hukum Menurut Mazhab Syafie" 2, 2018.

Nursidin, Ghilman. Konstruksi Pemikiran Maqâshid Syariah Imam al-Haramain al-Juwaini (Kajian Sosio-Histois), thesis, Semarang: IAIN Walisongo, 2012.

Syarifuddin, Amir . Ushul Fiqh, jilid.2, Jakarta: Logos Wacana Ilmu, 2001.

asy-Syâthibî, al-Muwâfaqat fi Ushîl al-Ahkâm, Jld II, IV, Beirut: Dar al-Fikr, tt.

Thahir, Halil. Ijtihad Maqasidi Rekonstruksi Hukum Islam Berbasis Interkoneksitas Maslahah, Yogyakarta: LKiS.

Umar, H.M. Hasbi. Nalar Figh Kontemporer. Jakarta: Penerbit Persada Press; 2007. 